\title{
Cervical Proprioception Impairment in Neck Pain- Pathophysiology, Clinical Evaluation, and Management: A Narrative Review
}

\author{
Baogan Peng $\cdot$ Liang Yang $\cdot$ Yongchao Li $\cdot$ Tanghua Liu • \\ Yanqing Liu
}

Received: October 20, 2020 / Accepted: December 16, 2020 / Published online: January 12, 2021

(c) The Author(s) 2021

\begin{abstract}
Neck pain is very common, but most of the causes are unknown, making diagnosis and treatment extremely challenging. Current studies have found that one of the main problems in patients with neck pain is the impairment of cervical proprioception, which subsequently leads to cervical sensorimotor control disturbances. Cervical spine has a very delicate proprioceptive system that plays a crucial role in controlling posture and balance. Cervical proprioceptive impairment in neck pain occurs through a variety of mechanisms. Experimental neck muscle pain induced by injection of hypertonic saline results in inhibition of the activation of painful muscle; chronic neck pain causes structural and functional impairment of cervical muscles; excessive
\end{abstract}

B. Peng $(\bowtie) \cdot$ L. Yang · Y. Li

Department of Spinal Surgery, The Third Medical Center, General Hospital of the Chinese People's Liberation Army, Beijing, China

e-mail: pengbaogan@163.com

T. Liu

Department of Algology, Lizhuang Tongji Hospital, Yibin, Sichuan, China

Y. Liu

Department of Algology, Beijing Tiantan Hospital, Capital Medical University, Beijing, China activation of mechanoreceptors in degenerative cervical discs and facet joints produces a large number of erroneous sensory signals. Clinical examinations to assess the link between structural pathology and neck pain have been unsuccessful, opening the way for the development of function-based tests. To date, eight neck sensorimotor control tests have been reported to evaluate patients with chronic neck pain. Although some tests may involve different subsystems (such as oculomotor system and vestibular system), all tests measure sensorimotor control in the neck, and the most commonly used is cervical joint position error (JPE) test. Current studies support the effectiveness of exercises targeting different aspects of sensorimotor function, in particular retraining aimed at improving cervical proprioception and muscle coordination. Based on the available evidence, it is recommended that patients with neck pain should be assessed and managed for cervical proprioceptive impairment and sensorimotor control disturbances.

Keywords: Cervical joint position error; Cervical proprioception; Cervical proprioceptor; Cervical sensorimotor control; Neck pain; Pathophysiology; Rehabilitation 


\section{Key Summary Points}

Neck pain is a common cause of disability worldwide, but its basic pathology and pathophysiology are still unclear.

Cervical spine has a very delicate proprioceptive system that plays a crucial role in controlling posture and balance.

One of the main problems of patients with neck pain is that the alteration of cervical proprioception leads to the disturbance of cervical sensorimotor control.

To date, eight neck sensorimotor control tests have been reported to evaluate patients with chronic neck pain, with the most commonly used test being the JPE test.

Studies support the effectiveness of exercises targeting different aspects of sensorimotor function, in particular retraining aimed at improving cervical proprioception and muscle coordination.

\section{DIGITAL FEATURES}

This article is published with digital features, including a summary slide, to facilitate understanding of the article. To view digital features for this article go to https://doi.org/10.6084/ m9.figshare.13379681.

\section{INTRODUCTION}

Neck pain is a common condition and one of the leading causes of disability worldwide, with mean estimates of $7.6 \%$ point prevalence (range, $5.9-38.7 \%$ ), 37\% annual prevalence (range, $16.7-75 \%$ ), and $48.5 \%$ lifetime prevalence (range, $14.2-71 \%$ ) [1]. Although neck pain can be attributed to traumatic (such as whiplash-associated) disorders, metabolic, neoplastic, inflammatory, or infectious diseases, most neck pain has no discernable cause and is considered to be idiopathic $[2,3]$. As with chronic low back pain, studies have failed to explore the consistent relationship between structural pathology and neck pain [2]. Current studies have indicated that one of the main problems in patients with neck pain is the cervical proprioception impairment, which leads to cervical sensorimotor control disturbances [4-6]. Cervical sensorimotor control involves central integration and processing of all the afferent information (i.e., visual, vestibular, and cervical proprioceptive inputs), and execution of the motor program through the cervical muscles, contributing to the maintenance of head posture and balance as well as the stability of cervical joints (Fig. 1) [4-7]. The cervical sensorimotor control disturbances secondary to neck pain are considered as a protective response to limit further stimulation of the painful tissue. Such disturbances may, in the long run, further cause tissue damage, aggravate pain through peripheral and central nervous system sensitization, and promote dysfunctional motion patterns [8].

The clinical practice guidelines for chronic, idiopathic neck pain do not support percutaneous or open surgical treatment, and recommend conservative treatment $[9,10]$. However, as conservative treatment usually fails to maintain long-term efficacy, clinical studies begin to pay attention to the evaluation and management of proprioceptive dysfunction in patients with idiopathic neck pain $[4,5,11-13]$. Based on the existing literature, this review aims to clarify the pathophysiology, assessment methods, and potential treatments of cervical proprioceptive impairment and sensorimotor control disturbances in patients with neck pain. This article is based on previously conducted studies and does not contain any studies with human participants or animals performed by any of the authors.

\section{SELECTION METHODS}

A comprehensive literature search was performed through PubMed and MEDLINE from the inception of the database to September 


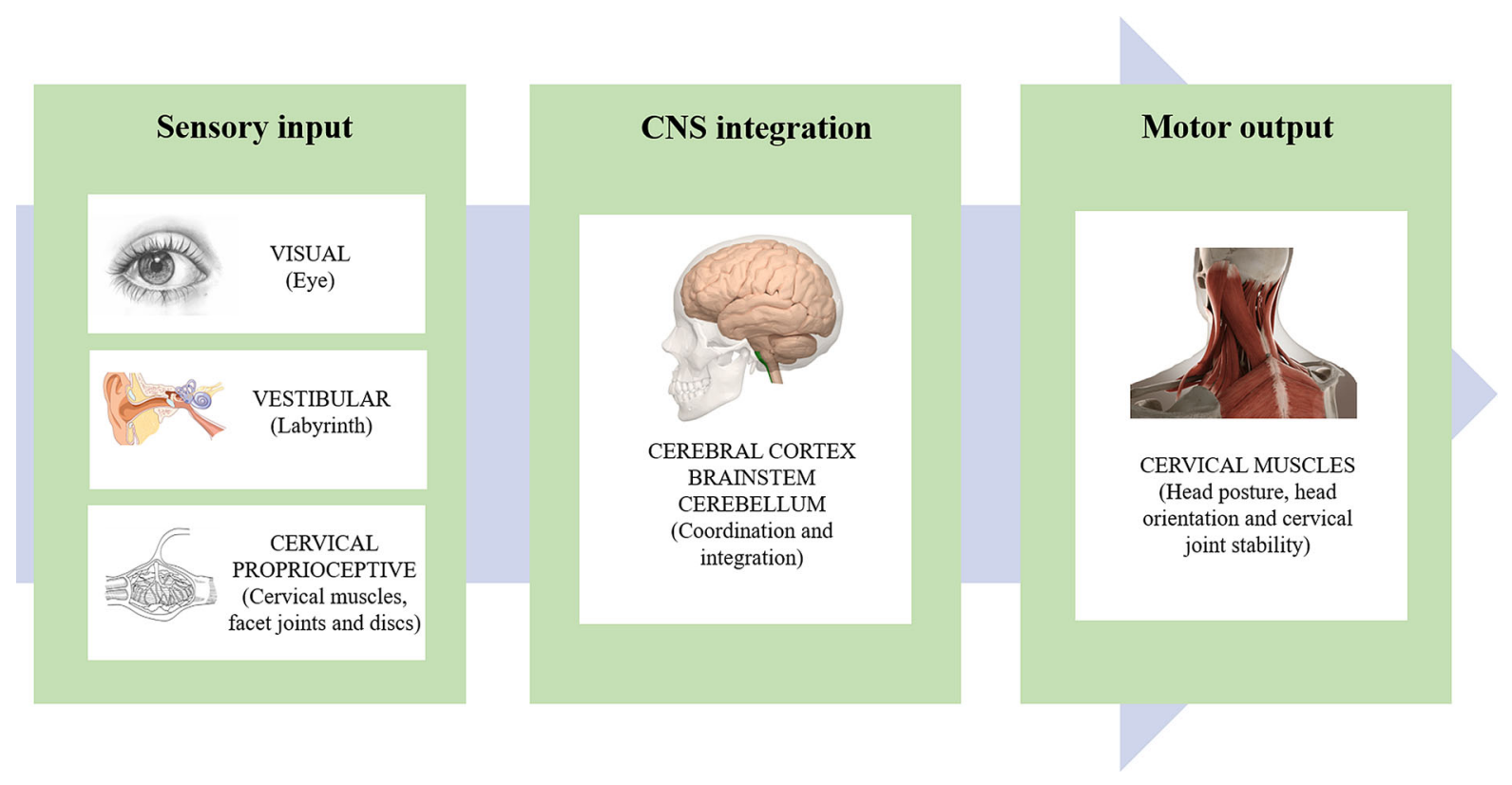

Fig. 1 Schematic diagram of cervical sensorimotor control

2020. The search terms included "neck pain", "cervical proprioception", "cervical sensorimotor control", "cervical joint position error", and "cervical proprioception impairment". References for this review were also identified from the personal libraries of the authors, supplemented by the reference lists of recent reviews and book chapters. Publications relevant to cervical proprioception impairment and sensorimotor control were selected based on author expertise to summarize our current understanding of the impact of neck pain on proprioception impairment. Systematic reviews and clinical trials, particularly randomized studies, were prioritized over lower-grade evidence.

\section{CERVICAL PROPRIOCEPTORS AND PROPRIOCEPTION}

Balance, posture, and motor coordination are common activities in daily life, which require accurate perception of the head's position in three-dimensional space [14]. The vestibular system provides information about the position of the head relative to gravity. The visual system uses external cues to identify the position of the head relative to the surrounding environment. We now know that the cervical spine has a very delicate proprioceptive system, which signals the position of the head relative to the trunk, coordinates the vestibular and visual systems and plays a crucial role in controlling posture and balance $[4,14,15]$.

\section{Distribution of Cervical Proprioceptors}

Studies have shown that the spindles of the cervical muscles are the major proprioceptors of the neck and not the joint capsules $[4,16]$. The spindle density of the cervical muscles is much higher than that of the shoulder and thigh muscles $[17,18]$. In general, high spindle density in small muscles is associated with fine motor tasks [19]. The deep cervical muscles in humans have shown high spindle content, particularly in small suboccipital muscles [18-22]. Complex integrative mechanisms involving head-eye coordination may require complex proprioceptive inputs from the neck muscles, which may account for their high spindle content [18].

Mechanoreceptors, Ruffini corpuscles, Pacinian corpuscles, and Golgi tendon organs have 


\section{CERVICAL JOINT POSITION ERROR TESTING}

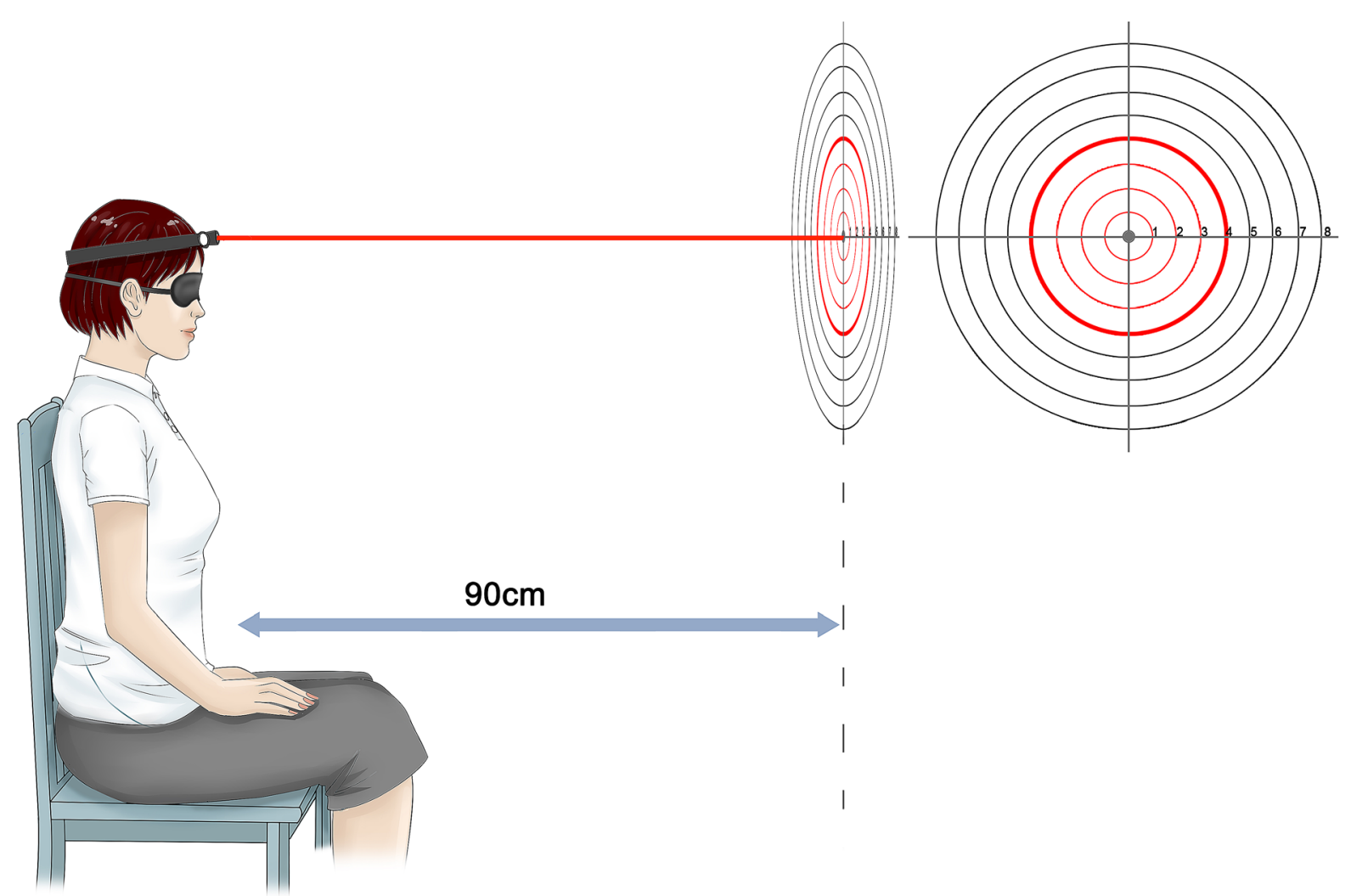

Fig. 2 Cervical joint position error (JPE) test using a laser pointer. The patient is sitting $90 \mathrm{~cm}$ from the wall, and the starting point (center of target or reference point) of the laser projection is marked. The patient (blindfolded or closed) performs active neck movement and then returns

been reported in human cervical facet joints $[23,24]$ and discs $[25,26]$. As with the peripheral joints [27, 28], there are only a small number of mechanoreceptors in the lumbar and cervical facet joints $[23,24]$. There was no significant difference in the distribution of receptors between the upper and lower cervical facet capsules [24]. As suggested by McLain, these findings may indicate that the role of these receptors in cervical proprioception is more limited [29]. Similarly, there are only a few proprioceptors in the cervical discs $[25,26]$. However, because the cervical disc is located on the axis of cervical motion, they are in a favorable position to detect subtle changes in the direction or position of the cervical spine [25]. to the starting position as accurately as possible. The final laser position is measured relative to the starting position (distance or angle). The errors are measured after cervical extension, flexion, lateral flexions, and rotations. Adapted from Treleaven [4] and Revel et al. [67]

\section{Density Changes of Cervical Proprioceptors}

The structures of cervical spine present degenerative changes with age, but the spindle characteristics such as the spindle distribution, morphology, and density in the cervical intrinsic muscles (longus colli and multifidus) remain unchanged [19]. So far, there is still a lack of comparative studies on the distribution of mechanoreceptors in normal and osteoarthritic cervical facet joints. Cervical facet joints and peripheral joints (such as hip and knee joints) are synovial joints and are anatomically similar. Moraes et al. [28] noted that the 
morphology of mechanoreceptors in the hip joint capsule did not seem to differ between healthy people and patients with osteoarthritis. Overall, the density of mechanoreceptors in the joint capsule is low, but in the joint capsule of osteoarthritis patients it is lower. The density of mechanoreceptors in patients with osteoarthritis is 0.044 per $\mathrm{mm}^{2}$, and in healthy people is 0.053 per $\mathrm{mm}^{2}[27,28]$. Recently, a comparative study by Yang et al. [25] found that Ruffini corpuscles were obviously increased in number and deeply ingrown into inner annulus fibrosus and even into nucleus pulposus in the diseased cervical discs from cervical spondylosis patients with dizziness in comparison with the discs from patients without dizziness and control discs. The densities of Ruffini corpuscles in anterior outer annulus fibrosus are 1.02, 0.6, and 0.33 per $\mathrm{mm}^{2}$ in patients with dizziness, patients without dizziness, and normal controls, respectively [25]. In addition, the authors [30] also found that a large number of Ruffini corpuscles and substance P-positive free nerve fibers grew in the degenerative cervical discs of patients with chronic neck pain and dizziness compared with the normal control group. These patients only showed degenerative changes of the cervical disc on imaging, without cervical disc herniation or nerve root compression. The studies suggest the degenerated cervical discs play a key role in impaired cervical proprioception.

Proprioceptive information is transmitted to the central nervous system through an encoding across populations of afferent receptors, the ensemble coding, rather than the discrete units from individual receptors [31-33]. In physiological conditions, cervical proprioceptive information from cervical muscle spindles and mechanoreceptors of cervical discs and facet joints is integrated and transmitted to the central nervous system to control head position, head orientation, and full-body posture $[29,34,35]$. Any dysfunction of these cervical sensory organs or asymmetry of afferent inputs can lead to a sensory mismatch between abnormal information (e.g., from degenerative discs) and normal information (e.g., from normal spindles) [35, 36].

\section{PATHOPHYSIOLOGY OF CERVICAL PROPRIOCEPTION IMPAIRMENT IN NECK PAIN}

\author{
Motor Control Impairment \\ in Experimental Neck Muscle Pain
}

It has been reported that patients with nonspecific neck pain have motor control impairments, but the specific deficits of the underlying regulatory system remain unclear [37]. Experimental muscle pain caused by injection of chemicals such as hypertonic saline provides a way to assess changes in motor control due to changes in afferent feedback. Experimental muscle pain often results in inhibition of the activation of painful muscles. The inhibition of muscle activity induced by pain has been observed to decrease the surface electromyographic (EMG) signal amplitude [38, 39] and motor unit discharge rate $[40,41]$. Since the force does not change when muscle activity decreases [38, 42], compensation mechanisms should appear in both painful and non-painful conditions to allow similar motor outputs. Muscle pain affects motor control strategies through central mechanisms [43, 44], including in the painful muscles [38] as well as in synergistic and antagonistic muscles [45]. In repetitive dynamic tasks, the nociceptive inputs from the upper trapezius by injection of hypertonic saline induces the reorganization of the coordinated activities of the three subdivisions of the trapezius muscle [46]. This is consistent with the pain adaptation model [47], and except for the decrease in painful muscle activity, the activity of the ipsilateral and contralateral non-painful muscle subdivisions increases [46].

Cervical spine is a complex biomechanical system consisting of innumerable degrees of freedom motion of each joint and at least 20 pairs of muscles, many of which perform similar functions [48]. The decrease in muscle activity due to neck pain can be compensated, for example, by reducing the activity of antagonist muscles or increasing the activity of synergistic muscles. An experimental study has shown that the local excitation of the noxious afferents in 
cervical muscles has an inhibitory effect on the painful muscles, which are offset at the level of the muscle group involved in the task by complex motor strategic reorganization. This change in muscle coordination is task-dependent, so motor output remains constant in the state of pain [48].

Acute neck pain induced by hypertonic saline injection at $\mathrm{C} 2 / 3$ level in the splenius capitis muscle on one side caused cervical proprioceptive disturbance with side-specific changes [49]. The clinical implications of this finding are that neck pain itself has a clear role in proprioception and neck sensorimotor control, and subsequently influence orientation. The main function of pain is to prevent further tissue damage. This corresponds to a decrease in muscle activity of the painful muscles, whose activity moves from deeper pained muscles to superficial muscles. It is likely that in neck pain, this transfer may interfere with normal proprioception [49].

\section{Cervical Muscle Impairment in Chronic Neck Pain}

A number of studies have indicated that patients with chronic neck pain may be associated with alterations in cervical motor behavior (timing and activation) [50-52], a decrease in cross-sectional area of cervical muscles [53] as well as muscular functional deficiencies in strength, endurance, precision and acuity, and range of motion [54]. Neck pain may cause maladaptive strategies, change the neck muscle coordination, and reduce the specificity of neck muscle activation, for instance, through reduced activation of the deep segmental muscles and increased activation of the superficial muscles [48, 54]. As mentioned above, muscle spindles densely packed in the deep neck muscles are the main source of proprioception afferents in the neck. These structural and functional changes in the cervical deep and superficial muscles can change the discharge of muscle spindles, which affects the afferent input and leads to alterations in proprioception $[13,55]$. The results suggest that the complexity and multifaceted nature of neck muscle impairment exists in people with chronic neck pain. In addition, the effect of pain on many levels of the nervous system can alter the sensitivity of muscle spindles and change the representation and regulation of the cortex to the cervical afferent input $[43,56,57]$.

\section{Functional Impairment of The Receptors in Degenerative Cervical Discs and Facet Joints}

Most chronic idiopathic neck pain is thought to arise from degenerative cervical discs and facet joints [3]. The degenerative changes in cervical discs and facet joints are always related to inflammation [58, 59]. In the inflammatory environment, the discharge characteristics of the mechanoreceptors will be excessively active, thereby producing erroneous sensory signals $[25,30]$.

The mechanoreceptors in the discs and facet joint capsules can monitor and control activity of paraspinal muscles. Electrical stimulation of mechanoreceptors in lumbar discs and capsules seems to induce reflex contraction of lumbar muscles. Similarly, mechanical stimulation of mechanoreceptors in the lumbar disc and facet capsule can excite the surrounding muscles [60]. Thus, the function of the cervical motor control is closely related to the cervical proprioceptive inputs from the cervical discs and facet joints, which are responsible for the optimal recruitment of cervical muscles. In the process of maintaining body balance, there are both coordination and competition among the balance organs $[36,61]$. In pathological conditions, such as cervical disc degeneration or facet osteoarthritis, the erroneous proprioceptive input distorts the direct linear interaction between neck proprioception and vestibular information, resulting in subjective body orientation and spatial psychological representation, which is manifested as dizziness or subjective unstable perception $[25,62]$. 
Table 1 Eight neck sensorimotor control tests*

\begin{tabular}{|c|c|c|c|}
\hline Test & Purpose & Measurement (units) & Method \\
\hline JPE & $\begin{array}{l}\text { Ability to reposition the head to a } \\
\text { given position }\end{array}$ & $\begin{array}{l}\text { Error from neutral head } \\
\text { position or target } \\
(\text { degree or } \mathrm{cm})\end{array}$ & $\begin{array}{l}\text { Participant sits in a chair facing a target on } \\
\text { a wall } 90 \mathrm{~cm} \text { away. A specific laser } \\
\text { pointer is placed on top of the head and } \\
\text { the participant is blindfolded. While } \\
\text { starting with the laser pointer exactly in } \\
\text { the center of the target, the participant is } \\
\text { instructed to move their head away from } \\
\text { the target. After returning to the center, } \\
\text { the error between starting position and } \\
\text { final position is assessed }\end{array}$ \\
\hline $\begin{array}{c}\text { Postural } \\
\text { sway }\end{array}$ & $\begin{array}{l}\text { Amount of movement during quiet } \\
\text { stance }\end{array}$ & $\begin{array}{l}\text { Sway area }\left(\mathrm{cm}^{2}\right) \text { or total } \\
\text { sway path }(\mathrm{mm})\end{array}$ & $\begin{array}{l}\text { Recorded during stance on a force platform } \\
\text { in both eyes-open and eyes-closed } \\
\text { conditions }\end{array}$ \\
\hline $\begin{array}{l}\text { Subjective } \\
\text { visual } \\
\text { vertical }\end{array}$ & $\begin{array}{l}\text { Ability to reposition the line } \\
\text { displayed on the screen so that it } \\
\text { is aligned with the true vertical } \\
\text { line }\end{array}$ & $\begin{array}{l}\text { Error from true vertical } \\
\quad(\text { degrees })\end{array}$ & $\begin{array}{l}\text { A tilted line appears on a computer screen, } \\
\text { disk, or virtual reality device. Participants } \\
\text { have to use a computer mouse or control } \\
\text { knob to reposition the line to align it } \\
\text { with the true vertical line }\end{array}$ \\
\hline $\begin{array}{l}\text { Head tilt } \\
\text { response }\end{array}$ & $\begin{array}{l}\text { Ability to position the stripe with } \\
\text { the true vertical line }\end{array}$ & $\begin{array}{l}\text { Error from true vertical } \\
\quad(\text { degree })\end{array}$ & $\begin{array}{l}\text { A tilted white stripe appears in a pair of } \\
\text { virtual reality goggles. The participant is } \\
\text { instructed to adjust the roll angle of the } \\
\text { head until the stripe is aligned with the } \\
\text { gravitational vertical }\end{array}$ \\
\hline $\begin{array}{l}\text { Smooth } \\
\text { pursuit } \\
\text { neck } \\
\text { torsion }\end{array}$ & $\begin{array}{l}\text { Eye movements while torso is } \\
\text { rotated relative to the head }\end{array}$ & $\begin{array}{l}\text { Ratio between eye and } \\
\text { target movement in } \\
\text { neutral and torsion } \\
\text { positions }\end{array}$ & $\begin{array}{l}\text { Participants focus their eyes on a moving } \\
\text { target and keep the head still, in a neutral } \\
\text { position, and a position in which the } \\
\text { torso is rotated relative to the head } \\
\text { (torsion). The velocity of eye movements } \\
\text { while following the target is recorded. } \\
\text { The gain (ratio between eye movement } \\
\text { and target movement) is calculated. The } \\
\text { outcome measure (smooth pursuit neck } \\
\text { torsion) is the difference between the } \\
\text { gain in neutral and the average gain in } \\
\text { torsion (right and left) }\end{array}$ \\
\hline
\end{tabular}


Table 1 continued

\begin{tabular}{|c|c|c|c|}
\hline Test & Purpose & Measurement (units) & Method \\
\hline The Fly & $\begin{array}{l}\text { Ability to track a computer- } \\
\text { displayed target moving in a } \\
\text { specific pattern }\end{array}$ & $\begin{array}{l}\text { Error from target }(\mathrm{cm} \text { or } \\
\mathrm{mm} \text { ) }\end{array}$ & $\begin{array}{l}\text { Participants track target (The Fly) on a } \\
\text { computer screen by moving their head } \\
\text { and neck. Fastrak system is used to } \\
\text { measure the accuracy. For different } \\
\text { difficulty levels (i.e., different fly pattens), } \\
\text { the accuracy of the performance is } \\
\text { reported }\end{array}$ \\
\hline $\begin{array}{l}\text { Head } \\
\text { steadiness }\end{array}$ & $\begin{array}{l}\text { Ability to hold the head still for a } \\
\text { period of time }\end{array}$ & $\begin{array}{l}\text { Angular velocity (degree/ } \\
\text { s) }\end{array}$ & $\begin{array}{l}\text { Head steadiness in terms of head motion } \\
\text { velocity is compared during two } 40 \\
\text { second isometric neck flexion tests at a } \\
\text { high-load test and a low-load test. } \\
\text { Increased velocity is expected to reflect } \\
\text { decreased head steadiness }\end{array}$ \\
\hline $\begin{array}{l}\text { Rod-and- } \\
\text { frame } \\
\text { test }\end{array}$ & $\begin{array}{l}\text { Ability to position an offset rod } \\
\text { into the vertical position }\end{array}$ & $\begin{array}{l}\text { Vertical perception error } \\
\text { (degree) }\end{array}$ & $\begin{array}{l}\text { Rod and frame are made up of a } \\
\text { luminescent vertical rod surrounded by a } \\
\text { square frame. Participants are placed in a } \\
\text { dark room where the only visual objects } \\
\text { are the luminescent vertical rod and } \\
\text { square frame. In the different test } \\
\text { process, the test rod or frame offset by } \\
\text { different degrees, and the subjects are } \\
\text { required to use the joystick to place the } \\
\text { rod vertically. The difference between } \\
\text { the real vertical line and the subject's } \\
\text { perception of the vertical line is } \\
\text { measured }\end{array}$ \\
\hline
\end{tabular}

Data in the table are based on Michiels et al. [7], Humphreys [14], and de Zoete et al. [78]

\section{Relationship Between Neck Pain and Cervical Proprioception Impairment}

Neck pain itself may interfere with afferent signals from the proprioceptors of the neck, leading to erroneous proprioceptive information. The system that conducts pain carries activity to motor neurons in the same spinal segment [63]. Therefore, increased pain increases muscle tension. Electrical stimulation of group III muscle afferents and intramuscular injection of hypertonic saline can significantly change the activity of leg muscle $\gamma$ - motoneurons in animals [44, 64]. The algesic chemical injection of the masseter muscle preferentially affects the amplitude sensitivity of jaw muscle spindle afferents, which is consistent with the effect on static $\gamma$-motoneurons [65]. The results suggest that pain-induced modulation of spindle afferent responses is mediated by small-diameter muscle afferents and that this modulation depends in part on the transmission of nociceptive information from the trigeminal subnucleus caudalis onto trigeminal $\gamma$-motoneurons [65]. According to the pathophysiological model [66], the 
metabolites produced by muscle contraction activate the muscle afferent nerves of groups III and IV, which in turn activates $\gamma$-motoneurons, supplying intrafusal fibers in both homomorphous and heteromorphic muscles, thereby increasing spindle stretching sensitivity and reflex-mediated muscle stiffness. In addition, the concentration of metabolites such as potassium, lactic acid, and arachidonic acid may directly sensitize different proprioceptors, leading to erroneous proprioceptive signals. Furthermore, the erroneous proprioceptive input can trigger the increased and prolonged reflex activation of neck muscles, which may lead to neck pain over time, thus forming a vicious circle [60].

\section{CLINICAL ASSESSMENT OF SENSORIMOTOR CONTROL IN CHRONIC NECK PAIN}

\section{Neck Sensorimotor Control Tests}

The vestibular, visual, and cervical proprioceptive systems have unique central and reflex connections and integration [4]. As mentioned before, the cervical sensorimotor control system in patients with idiopathic neck pain has been affected due to impaired proprioception. To date, eight neck sensorimotor control tests have been reported to evaluate patients with idiopathic neck pain: joint position error (JPE) [67], postural sway $[67,68]$, subjective visual vertical [69], head tilt response [70], The Fly [71], smooth pursuit neck torsion [72, 73], head steadiness [74], and rod-and-frame test (a summary of eight neck sensorimotor control tests is shown in Table 1) $[14,75,76]$. Although some tests may involve different subsystems (such as oculomotor system and vestibular system), all tests measure sensorimotor control in the neck, and the most commonly used is JPE test [77]. However, it is difficult to compare test results due to the different tasks required or the techniques used to quantify the measurements. In addition, it is not clear whether different measurement methods are equally reliable and effective, and which test is preferred [7]. A recent study [78] compared seven tests (all except the rod-and-frame test) in 50 patients with chronic idiopathic neck pain and found that different tests measured different components of sensorimotor control. The study implies that all seven tests are independent of each other. It is not possible to recommend a test battery for clinical practice.

\section{JPE Test}

Cervical joint position sense (JPS) is a major component of proprioception, and mainly reflects the ascending input (afferent) of cervical muscle, disc, capsule, and ligament receptors [79]. Abnormal cervical afferent input leads to an impaired cervical JPS, which is measured as cervical JPE [68]. Several methods exist to study cervical JPE, and the most commonly used is active motion angle reconstruction test and requires subjects to relocate a neutral head position or a predefined target head position without visual assistance selected by the researchers (Fig. 3). In the study of head position sense measurement, the measured variable is the difference between the initially determined reference point position (neutral or target position) and the position produced when the subjects try to match the target position. This difference is called JPE and the angle is in degrees $\left(^{\circ}\right)$ [80]. The test has been widely used to distinguish patients with chronic neck pain from the healthy control group [11, 12, 79].

Revel et al. [67] firstly reported that patients with chronic neck pain showed poorer ability $\left(6.11^{\circ}\right)$ to restore the original position of the head after actively rotating the head to the maximum extent compared with healthy subjects $\left(3.50^{\circ}\right)$. They suggested changing the proprioception of the neck to account for their findings. Alahmari et al. [81] compared the JPE of 42 patients with chronic neck pain and 42 age-matched healthy people, and found that the patients had a greater error in all movement directions tested $(p<0.001)$. Similarly, other studies have revealed a significant greater error in patients with chronic idiopathic neck pain when compared with asymptomatic controls, despite the variability in methods used in these 


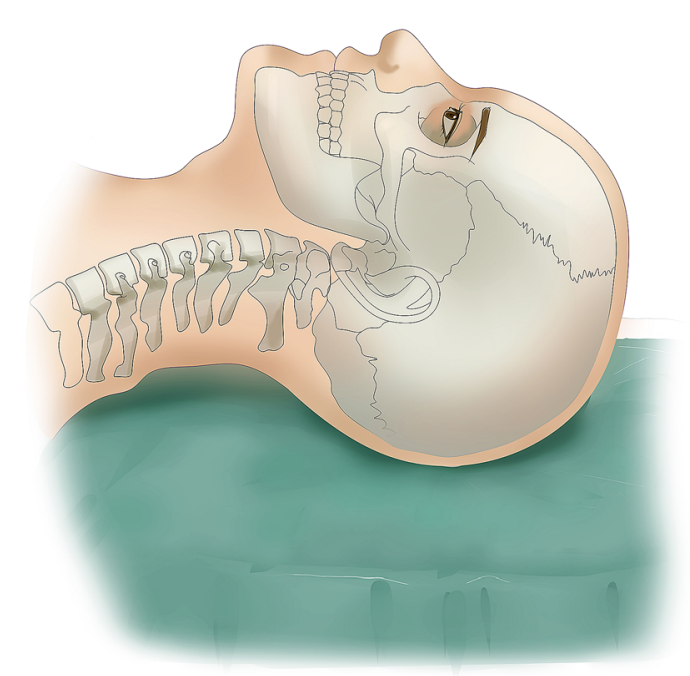

Fig. 3 Craniocervical flexion test. During craniocervical flexion test, the patient is positioned supine in crook lying with the neck in a neutral position (no pillow), making the line of the face horizontal. An uninflated pressure sensor is placed behind the neck so that it is close to the occiput and inflated to a baseline pressure of $20 \mathrm{mmHg}$, which is sufficient to fill the space between the table surface and the cervical lordotic curve, but does not push the neck into the lordosis. The device provides feedback and guidance to the patient to perform the five test phases required, with an

studies [68, 82-87]. Cervical proprioceptive errors in the patients with cervical spondylosis were also shown to be significantly larger than those of the healthy control group, indicating that the cervical proprioception in the cervical spondylosis was impaired [55]. A systematic review including 14 studies suggested that JPE was significantly higher in the neck pain group than in the control group [79]. De Zoete et al. [77] in a systematic review and meta-analysis revealed a significant difference between idiopathic neck pain and healthy groups in JPE testing, indicating that this test may be clinically useful in assessing sensorimotor control. Similarly, another systematic review and metaanalysis conducted by Stanton et al. [11] aimed to synthesize and critically evaluate the available evidence for proprioceptive dysfunction in patients with chronic idiopathic neck pain by comparing the JPE of asymptomatic controls. Pooled estimates showed that people with chronic idiopathic neck pain had moderately

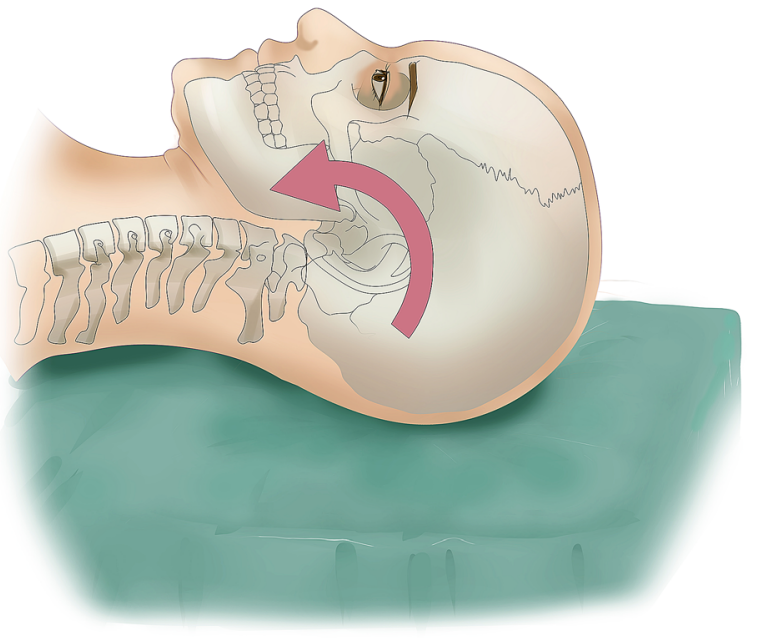

additional $2 \mathrm{mmHg}$ per phase and a maximum of $30 \mathrm{mmHg}$. The patient is asked to hold each position for $10 \mathrm{~s}$. There is a 10-s break between the two stages. The figure shows the starting position (left) and the end position of craniocervical flexion (right). The craniocervical flexion includes the head nodding "yes" movement to keep it in contact with the supporting surface, and the flexion movement mainly occurs in the upper neck motion segments. Adapted from Jull et al. [104] and Falla et al. [106]

impaired cervical JPS during head-to-neutral repositioning tests, compared with asymptomatic controls.

\section{Differences in JPE Test}

It is difficult to quantify pain and sensorimotor control. Although pain can be described and graded subjectively, sensorimotor control is more difficult to understand. In JPE testing, since the neutral neck position is a commonly used position, the memory head position may be recalled during the test [87]. Recall of the head position in a memory may involve more than one sensory component because memory may not only rely on proprioception. Therefore, the validity of this test in evaluating sensorimotor control may be limited. In studies using a preset target in the transverse plane, recall of the head position was less likely because the head was in a less common position on the neck. The head repositioning test makes 
indirect evaluation of proprioception possible [88]. However, the results vary greatly. Although most studies have reported reduced sensorimotor control in patients with neck pain, other studies $[88,89]$ have reported that patients with subclinical neck pain have fewer relocation errors than controls. Rix et al. [86] and Palmgren et al. [90] found that people with chronic, nontraumatic neck pain were no less accurate in head repositioning than healthy controls for all movement directions except flexion. In addition, other studies have reported that there is no measurable effect on cervical proprioception in the case of cervical pain [91-93]. In general, these findings contradict the theory that the change of position sense may be due to the nociceptive input, or the pain experienced in the position-matching task provides additional feedback to improve the accuracy of position matching [29]. These contradictory results suggest the multifaceted nature of neck pain and the different mechanisms in sensorimotor control. For example, muscle fatigue and/or muscle tension and central nervous system regulation may change sensorimotor control [55]. Pain itself may interfere with muscle activity or adaptation of exercise strategies [49]. Cervical proprioception errors were significantly and positively correlated with the intensity of neck pain, indicating that the increase in pain intensity will impair proprioception [55, 94]. Different pain time courses such as acute, subacute, or persistent pain may have different effects on sensorimotor control [92]. Persistent pain may cause morphological changes in muscle components $[53,54]$. In addition, an increase of age was thought to be related to the increase of cervical JPE. In elderly subjects, neck muscle strength decline, sedentary lifestyle, memory decline, and cognitive or motor impairment may result in damage to the target reproduction test $[80,81]$. However, the literature on the relationship between age and JPE is contradictory $[81,83]$, which suggests that there may be other factors beyond age that affect the cervical proprioception [95]. Therefore, many causes may affect the proprioception and sensorimotor control of cervical spine.

\section{REHABILITATION \\ OF SENSORIMOTOR CONTROL IN CHRONIC NECK PAIN}

Evidence to date suggests that the management of sensorimotor control disturbances due to chronic neck pain may need to address the primary causes and secondary effects of alterations in proprioceptive activity $[4,5,12,13,96]$. Local treatments to relieve neck pain are not discussed here. The focus now is primarily on tailored programs that address different aspects of sensorimotor control disturbances, such as training aimed at improving proprioception and muscle coordination.

\section{Proprioceptive Retraining}

After a rehabilitation program based on eye-head coupling exercises aimed to improve proprioception in the neck, Revel et al. [12] found that the ability to reposition the head after rotation was significantly improved, and neck pain was significantly reduced. There was no significant change in JPE in the control group. Jull et al. [13] achieved similar results in a group of patients with chronic neck pain using proprioceptive training. A randomized clinical trial evaluated the impact of balance training on JPS in patients with chronic neck pain, and found that joint repositioning accuracy was improved and pain was reduced in the intervention group, while no effect was observed in the control group [97]. Another randomized control trial revealed that proprioceptive training with a gaze direction recognition exercise combined with conventional physical therapy was more effective than conventional physical therapy for patients with chronic neck pain in improving neck disability and balance [98]. In a doubleblind, randomized controlled trial, Saadat et al. [99] demonstrated that sensorimotor training combined with traditional physical therapy exercises could be more effective than traditional exercise alone in improving JPS, endurance, dynamic balance, and walking speed in patients with chronic neck pain (Table 2). 
Table 2 Proprioceptive training in patients with neck pain and clinical outcomes

\begin{tabular}{|c|c|c|c|c|c|c|}
\hline Study & $\begin{array}{l}\text { Study } \\
\text { design }\end{array}$ & Participants & Interventions & $\begin{array}{l}\text { Main outcome } \\
\text { measures }\end{array}$ & Results & Main findings \\
\hline $\begin{array}{l}\text { Revel } \\
\text { et al. } \\
{[12]}\end{array}$ & RCT & $\begin{array}{l}\text { Sixty participants } \\
\text { with chronic } \\
\text { neck pain were } \\
\text { randomly } \\
\text { allocated to a } \\
\text { rehabilitation } \\
\text { group and a } \\
\text { control group }\end{array}$ & $\begin{array}{l}\text { The rehabilitation } \\
\text { group received a } \\
\text { rehabilitation } \\
\text { program and } \\
\text { common } \\
\text { symptomatic } \\
\text { treatment (e.g., } \\
\text { nonsteroidal } \\
\text { anti- } \\
\text { inflammatory } \\
\text { drugs, analgesic } \\
\text { drugs); the } \\
\text { control group } \\
\text { received only } \\
\text { symptomatic } \\
\text { treatment } \\
\text { without } \\
\text { rehabilitation } \\
\text { The rehabilitation } \\
\text { program } \\
\text { included head } \\
\text { relocation } \\
\text { practice, gaze } \\
\text { stability, eye- } \\
\text { follow and } \\
\text { eye-head } \\
\text { coordination } \\
\text { exercises and } \\
\text { 30-40 min at a } \\
\text { time, twice a } \\
\text { week for } 8 \text { weeks }\end{array}$ & $\begin{array}{l}\text { HRA; neck } \\
\text { pain (VAS, } \\
0-100)\end{array}$ & $\begin{array}{l}\text { Greater gain in } \\
\text { HRA and more } \\
\text { improved neck } \\
\text { pain were } \\
\text { observed in the } \\
\text { rehabilitation } \\
\text { group than in } \\
\text { the control } \\
\text { group }\end{array}$ & $\begin{array}{l}\text { A rehabilitation } \\
\text { program based } \\
\text { on eye-head } \\
\text { coupling should } \\
\text { be included in } \\
\text { most medical } \\
\text { management of } \\
\text { cervicalgic } \\
\text { patients }\end{array}$ \\
\hline
\end{tabular}


Table 2 continued

\begin{tabular}{|c|c|c|c|c|c|c|}
\hline Study & $\begin{array}{l}\text { Study } \\
\text { design }\end{array}$ & Participants & Interventions & $\begin{array}{l}\text { Main outcome } \\
\text { measures }\end{array}$ & Results & Main findings \\
\hline $\begin{array}{l}\text { Jull et al. } \\
\qquad[13]\end{array}$ & RCT & $\begin{array}{l}\text { Sixty-four female } \\
\text { subjects with } \\
\text { persistent neck } \\
\text { pain and deficits } \\
\text { in JPE were } \\
\text { randomized into } \\
\text { two exercise } \\
\text { groups: } \\
\text { proprioceptive } \\
\text { training or } \\
\text { craniocervical } \\
\text { flexion training }\end{array}$ & $\begin{array}{l}\text { Proprioceptive } \\
\text { training } \\
\text { included head } \\
\text { relocation } \\
\text { practice, gaze } \\
\text { stability, eye- } \\
\text { follow and } \\
\text { eye-head } \\
\text { coordination } \\
\text { exercises. } \\
\text { Craniocervical } \\
\text { flexion training } \\
\text { included the } \\
\text { low-load } \\
\text { training of the } \\
\text { craniocervical } \\
\text { flexor muscles } \\
\text { Less than } 30 \text { min } \\
\text { at a time, once a } \\
\text { week for } 6 \text { weeks }\end{array}$ & $\begin{array}{l}\text { JPE; NDI; } \\
\text { neck pain } \\
\text { (NRS, 0-10) }\end{array}$ & $\begin{array}{l}\text { A significant } \\
\text { decrease in JPE, } \\
\text { neck pain } \\
\text { intensity, and } \\
\text { perceived } \\
\text { disability was } \\
\text { identified for } \\
\text { both the } \\
\text { proprioceptive } \\
\text { training group } \\
\text { and the } \\
\text { craniocervical } \\
\text { flexion training } \\
\text { group. However, } \\
\text { the } \\
\text { proprioceptive } \\
\text { training group } \\
\text { had a greater } \\
\text { reduction in JPE } \\
\text { from right } \\
\text { rotation } \\
\text { compared to the } \\
\text { craniocervical } \\
\text { flexion training } \\
\text { group }\end{array}$ & $\begin{array}{l}\text { Both } \\
\text { proprioceptive } \\
\text { training and } \\
\text { craniocervical } \\
\text { flexion training } \\
\text { have a } \\
\text { demonstrable } \\
\text { benefit on } \\
\text { impaired cervical } \\
\text { JPE in people } \\
\text { with neck pain, } \\
\text { with marginally } \\
\text { more benefit } \\
\text { gained from } \\
\text { proprioceptive } \\
\text { training }\end{array}$ \\
\hline
\end{tabular}


Table 2 continued

\begin{tabular}{|c|c|c|c|c|c|c|}
\hline Study & $\begin{array}{l}\text { Study } \\
\text { design }\end{array}$ & Participants & Interventions & $\begin{array}{l}\text { Main outcome } \\
\text { measures }\end{array}$ & Results & Main findings \\
\hline $\begin{array}{l}\text { Beinert } \\
\text { and } \\
\text { Taube } \\
{[97]}\end{array}$ & RCT & $\begin{array}{l}\text { Thirty-four } \\
\text { patients with } \\
\text { subclinical neck } \\
\text { pain were } \\
\text { randomly } \\
\text { assigned to } \\
\text { balance training } \\
\text { (intervention } \\
\text { group) or to stay } \\
\text { active (control } \\
\text { group) }\end{array}$ & $\begin{array}{l}\text { The intervention } \\
\text { consisted of } \\
\text { three balance } \\
\text { tasks: single leg } \\
\text { stance, tandem } \\
\text { stance and } \\
\text { standing on a } \\
\text { wobble board. } \\
\text { Each task was } \\
\text { performed for } \\
20 \text { s with a } 10-s \\
\text { break in between } \\
15 \text { mins at a time, } \\
3 \text { times a week } \\
\text { for } 5 \text { weeks }\end{array}$ & $\begin{array}{l}\text { NHP; RHP; } \\
\text { neck pain } \\
(\text { NRS,0-10) }\end{array}$ & $\begin{array}{l}\text { The intervention } \\
\text { group showed } \\
\text { improved joint } \\
\text { repositioning } \\
\text { accuracy and } \\
\text { decreased pain, } \\
\text { whereas no } \\
\text { effects were } \\
\text { observed in the } \\
\text { control group. A } \\
\text { weak correlation } \\
\text { was identified } \\
\text { between reduced } \\
\text { neck pain } \\
\text { intensity and } \\
\text { improved joint } \\
\text { repositioning }\end{array}$ & $\begin{array}{l}\text { Balance training } \\
\text { can effectively } \\
\text { improve cervical } \\
\text { sensorimotor } \\
\text { function and } \\
\text { decrease } \\
\text { neck pain intensity }\end{array}$ \\
\hline $\begin{array}{l}\text { Duray } \\
\text { et al. } \\
{[98]}\end{array}$ & RCT & $\begin{array}{l}\text { Forty patients } \\
\text { with chronic } \\
\text { neck pain were } \\
\text { randomly } \\
\text { divided into } \\
\text { study and } \\
\text { control groups }\end{array}$ & $\begin{array}{l}\text { The study group } \\
\text { received } \\
\text { conventional } \\
\text { physical therapy } \\
\text { and gaze } \\
\text { direction } \\
\text { recognition } \\
\text { exercise for } \\
\text { proprioceptive } \\
\text { training; the } \\
\text { control group } \\
\text { received only } \\
\text { conventional } \\
\text { physical therapy } \\
\text { Exercises were } \\
\text { performed for } \\
3 \text { weeks with five } \\
\text { sessions per week }\end{array}$ & $\begin{array}{l}\text { FSST; } \\
\text { SLBT; } \\
\text { NDI; neck } \\
\text { pain } \\
\text { (VAS,0-10) }\end{array}$ & $\begin{array}{l}\text { The study group } \\
\text { tended to show } \\
\text { higher SLBT } \\
\text { with eyes } \\
\text { opened and } \\
\text { closed scores and } \\
\text { lower neck pain } \\
\text { intensity, FSST } \\
\text { scores, and neck } \\
\text { disability levels } \\
\text { after the } \\
\text { treatment. } \\
\text { However, no } \\
\text { significant } \\
\text { differences were } \\
\text { observed except } \\
\text { for in pain } \\
\text { intensity scores } \\
\text { in the control } \\
\text { group }\end{array}$ & $\begin{array}{l}\text { Proprioceptive } \\
\text { training should } \\
\text { be included in } \\
\text { physiotherapy } \\
\text { programs to } \\
\text { improve balance; } \\
\text { it decreases the } \\
\text { disability level in } \\
\text { patients with } \\
\text { chronic neck } \\
\text { pain }\end{array}$ \\
\hline
\end{tabular}


Table 2 continued

\begin{tabular}{|c|c|c|c|c|c|c|}
\hline Study & $\begin{array}{l}\text { Study } \\
\text { design }\end{array}$ & Participants & Interventions & $\begin{array}{l}\text { Main outcome } \\
\text { measures }\end{array}$ & Results & Main findings \\
\hline $\begin{array}{c}\text { Saadat } \\
\text { et al. } \\
\text { [99] }\end{array}$ & $\begin{array}{c}\text { Double- } \\
\text { blind, } \\
\text { RCT }\end{array}$ & $\begin{array}{l}\text { Fifty-three patients } \\
\text { with chronic } \\
\text { non-specific } \\
\text { neck pain were } \\
\text { randomized to } \\
\text { either traditional } \\
\text { or combined } \\
\text { exercise groups }\end{array}$ & $\begin{array}{l}\text { The traditional } \\
\text { group performed } \\
\text { traditional } \\
\text { exercises, and } \\
\text { the combined } \\
\text { exercise group } \\
\text { performed } \\
\text { sensorimotor } \\
\text { training in } \\
\text { addition to } \\
\text { traditional } \\
\text { exercises. This } \\
\text { sensorimotor } \\
\text { training } \\
\text { program } \\
\text { comprised three } \\
\text { parts: retraining } \\
\text { joint position } \\
\text { and movement } \\
\text { sense, } \\
\text { oculomotor } \\
\text { exercises, and } \\
\text { balance training } \\
\text { All patients } \\
\text { received } 12 \\
\text { sessions of } \\
\text { supervised } \\
\text { intervention } 3 \\
\text { times per week }\end{array}$ & $\begin{array}{l}\text { JPS; neck pain } \\
\text { (VAS,0-10), } \\
\text { NFMET, } \\
\text { 10-m walk } \\
\text { test, step test, } \\
\text { and NDI }\end{array}$ & $\begin{array}{l}\text { The combined } \\
\text { exercise group } \\
\text { showed } \\
\text { significantly } \\
\text { greater } \\
\text { improvement } \\
\text { compared to the } \\
\text { traditional group } \\
\text { in joint position } \\
\text { sense, the 10-m } \\
\text { walk test, and the } \\
\text { step test. Pain } \\
\text { intensity, muscle } \\
\text { endurance, and } \\
\text { disability } \\
\text { improved in } \\
\text { both groups }\end{array}$ & $\begin{array}{l}\text { A combination of } \\
\text { sensorimotor } \\
\text { training with } \\
\text { traditional } \\
\text { physical therapy } \\
\text { exercises could } \\
\text { be more } \\
\text { effective than } \\
\text { traditional } \\
\text { exercises alone } \\
\text { in improving } \\
\text { joint position } \\
\text { sense, } \\
\text { endurance, } \\
\text { dynamic } \\
\text { balance, and } \\
\text { walking speed }\end{array}$ \\
\hline
\end{tabular}

$R C T$ randomized controlled trial, $H R A$ head repositioning accuracy, $V A S$ visual analogue scale, JPE cervical joint position error, NDI Neck Disability Index, NRS Numerical rating scale, $N H P$ neutral head position, RHP pre-rotated head positions, FSST four step square tests, SLBT single leg balance test, NFMET neck flexor muscle endurance test

\section{Retraining of Deep Cervical Flexor Muscles}

Deep muscles are important for maintaining neck posture. The support of the cervical segments mainly depends on the muscular sleeve formed by the longus colli muscle anteriorly and the semispinalis cervicis and cervical multifidus muscles posteriorly [100]. In order to stabilize the cervical segments, the deep cervical muscle activity should cooperate with the superficial muscle activity [101, 102]. Recent studies have found that the activation of deep flexors, the longus colli and longus capitis, is impaired in patients with neck pain $[50,51]$. 
There is evidence that the strength and endurance of the craniocervical and cervical flexors decrease in the patients with neck pain, and therefore rehabilitation is required [103]. The muscle impairment determined by the craniocervical flexion test seems to be the common feature of various neck pain. These observations prompted the use of the craniocervical flexion test (Fig. 3) to retrain the deep cervical flexor muscles in the motor relearning program for patients with neck pain [104]. Craniocervical flexion training increased deep cervical flexor muscle EMG amplitude and decreased sternocleidomastoid and anterior scalene muscle EMG amplitude across all stages of the craniocervical flexion test [103]. In clinical exercise of craniocervical flexion, retraining the deep cervical flexors can improve the function of cervical proprioception, maintain neutral posture, increase the activation and endurance of the deep cervical flexors, and reduce the neck symptoms $[13,100,105,106]$.

\section{Retraining of Deep Cervical Extensor Muscles}

The deep cervical extensor muscles are anatomically capable of coordinating cervical segmental movement with the deep cervical flexors [107]. The cervical extensor muscles are considered equally important in the recovery of patients with neck pain [108]. In patients with neck pain, the activity of superficial cervical extensors is enhanced and delayed offset (relaxation) after the activity [107, 109]. Compared with healthy controls, patients with neck pain showed structural and functional changes in the deep cervical extensor muscles [110-117], emphasizing the importance of exercise in improving performance. Specific exercises of the deep neck extensors have not been extensively studied. A muscle functional magnetic resonance imaging study [118] in a group of healthy volunteers showed that both the deep and superficial extensors were activated below the C2 level when an isometric neutral head/neck extension was performed at $20 \%$ of the maximum voluntary force. Compared with the exercise in the neutral position, the same exercise in $15^{\circ}$ of craniocervical extension increased the activity of the semispinalis capitis muscle, but not the deep extensor muscles below the C2 level. This is to be expected, because multifidus and semispinalis cervicis are the highest adherent to $\mathrm{C} 2$ and are therefore less affected by craniocervical extension. The results provided some preliminary insights into the impact of craniocervical orientation in response to different deep and superficial cervical extensors during performing cervical extensor exercises. O 'Leary et al. [119] then used the same method to compare the cervical extensor response patterns in patients with chronic neck pain with healthy controls, suggesting some alteration in the differential activation in cervical extensors in patients with chronic neck pain. High-load exercise is also recommended to increase muscle strength and endurance [107]. Twelve weeks of specific cervical resistance training resulted in a $34 \%$ increase in head-extension strength in healthy subjects [120]. Cross-sectional area increased by nearly $25 \%$ in splenius capitis, semispinalis capitis, semispinalis cervicis, and the multifidus, showing important hypertrophic effects [121]. A study using intramuscular EMG investigated the activity of the deep semispinalis cervicis and the superficial splenius capitis muscle at two spinal levels (C2 and C5) in healthy volunteers, and displayed the activation of the semispinalis cervicis relative to the splenius capitis when manual resistance was applied in extension over the vertebral arches (C1 and C4) [122]. A similar study in a group of women with chronic neck pain showed that localized resistance selectively activated the semispinalis cervicis muscle [123].

\section{ETIOLOGICAL MANAGEMENT OF NECK PAIN}

Eliminating acute neck pain and preventing it from developing into chronic neck pain are important for optimal management. If pain occurs, the cause should be analyzed and resolved during treatment. Proprioceptive input of the muscle spindles can be reduced by reducing neck pain. However, there is a lack of 
research in this area. The reduction in neck muscle tension caused by neck pain is important to improve postural performance. This, in turn, may lead to the normalization of proprioceptive signals in the neck muscles, reducing sensory mismatch. Cervical discogenic pain and cervical facet joint pain are the two main causes of chronic neck pain, accounting for $15-53 \%$ [124] and 40-55\% [125] respectively. Management aimed at eliminating inflammation in cervical disc and facet joint is particularly important in theory. It can not only reduce the sensitivity of nociceptors but also the sensitivity of proprioceptors. The difficulty lies in the lack of specific diagnostic methods for cervical discogenic pain and facet joint pain $[124,125]$.

\section{CONCLUSIONS}

Neck pain is a common cause of disability worldwide, but its basic pathology and pathophysiology are still unclear. One of the main problems of patients with neck pain is that the impairment of cervical proprioception leads to the disturbance of cervical sensorimotor control. Current studies recommend training on different aspects of sensorimotor function, particularly retraining aimed at improving proprioception and muscle coordination in the neck. Overall, the recommended clinical evaluation and management of sensorimotor control disturbances are based on currently available evidence, but this is an emerging field that requires more extensive studies to refine and determine the evaluation methods and determine the best strategy for treating the disturbances in patients with chronic neck pain $[4,126]$.

\section{ACKNOWLEDGEMENTS}

Funding. No funding or sponsorship was received for this study or publication of this article.

Authorship. All named authors meet the International Committee of Medical Journal Editors (ICMJE) criteria for authorship for this article, take responsibility for the integrity of the work as a whole, and have given their approval for this version to be published.

Authorship Contributions. All authors contributed equally to the manuscript.

Disclosures. Baogan Peng, Liang Yang, Yongchao Li, Tanghua Liu, and Yanqing Liu have nothing to disclose.

Compliance With Ethics Guidelines. This article is based on previously conducted studies and does not contain any studies with human participants or animals performed by any of the authors.

Data Availability. Data sharing is not applicable to this article as no datasets were generated or analyzed during the current study.

Open Access. This article is licensed under a Creative Commons Attribution-NonCommercial 4.0 International License, which permits any non-commercial use, sharing, adaptation, distribution and reproduction in any medium or format, as long as you give appropriate credit to the original author(s) and the source, provide a link to the Creative Commons licence, and indicate if changes were made. The images or other third party material in this article are included in the article's Creative Commons licence, unless indicated otherwise in a credit line to the material. If material is not included in the article's Creative Commons licence and your intended use is not permitted by statutory regulation or exceeds the permitted use, you will need to obtain permission directly from the copyright holder. To view a copy of this licence, visit http://creativecommons.org/licenses/by$\mathrm{nc} / 4.0 /$.

\section{REFERENCES}

1. Fejer R, Kyvik KO, Hartvigsen J. The prevalence of neck pain in the world population: a systematic critical review of the literature. Eur Spine J. 2006;15(6):834-48. 
2. Evans G. Identifying and treating the causes of neck pain. Med Clin North Am. 2014;98(3):645-61.

3. Cohen SP, Hooten WM. Advances in the diagnosis and management of neck pain. BMJ. 2017;358: j3221.

4. Treleaven J. Sensorimotor disturbances in neck disorders affecting postural stability, head and eye movement control. Man Ther. 2008;13(1):2-11.

5. Treleaven J. Sensorimotor disturbances in neck disorders affecting postural stability, head and eye movement control-Part 2: case studies. Man Ther. 2008;13(3):266-75.

6. Treleaven J. Dizziness, unsteadiness, visual disturbances, and sensorimotor control in traumatic neck pain. J Orthop Sports Phys Ther. 2017;47(7): 492-502.

7. Michiels S, De Hertogh W, Truijen S, November D, Wuyts F, Van de Heyning P. The assessment of cervical sensory motor control: a systematic review focusing on measuring methods and their clinimetric characteristics. Gait Posture. 2013;38(1):1-7.

8. McCaskey MA, Schuster-Amft C, Wirth B, Suica Z, de Bruin ED. Effects of proprioceptive exercises on pain and function in chronic neck- and low back pain rehabilitation: a systematic literature review. BMC Musculoskelet Disord. 2014;15:382.

9. Carragee EJ, Hurwitz EL, Cheng I, et al. Treatment of neck pain: injections and surgical interventions: results of the Bone and Joint Decade 2000-2010 Task Force on Neck Pain and Its Associated Disorders. Spine (Phila Pa 1976). 2008;33(4 Suppl): S153-S169.

10. Childs JD, Cleland JA, Elliott JM, et al. Neck pain: clinical practice guidelines linked to the International Classification of Functioning, Disability, and Health from the Orthopedic Section of the American Physical Therapy Association. J Orthop Sports Phys Ther. 2008;38(9):A1-34.

11. Stanton TR, Leake HB, Chalmers KJ, Moseley GL. Evidence of impaired proprioception in chronic, idiopathic neck pain: systematic review and metaanalysis. Phys Ther. 2016;96(6):876-87.

12. Revel M, Minguet M, Gregoy P, Vaillant J, Manuel JL. Changes in cervicocephalic kinesthesia after a proprioceptive rehabilitation program in patients with neck pain: a randomized controlled study. Arch Phys Med Rehabil. 1994;75(8):895-9.

13. Jull G, Falla D, Treleaven J, Hodges P, Vicenzino B. Retraining cervical joint position sense: the effect of two exercise regimes. J Orthop Res. 2007;25(3): 404-12.
14. Humphreys BK. Cervical outcome measures: testing for postural stability and balance. J Manipulative Physiol Ther. 2008;31(7):540-6.

15. Mergner T, Nasios G, Maurer C, Becker W. Visual object localisation in space. Interaction of retinal, eye position, vestibular and neck proprioceptive information. Exp Brain Res. 2001;141(1):33-51.

16. Richmond FJ, Abrahams VC. What are the proprioceptors of the neck? Prog Brain Res. 1979;50: 245-54.

17. Cooper S, Daniel PM. Muscle spindles in man; their morphology in the lumbricals and the deep muscles of the neck. Brain. 1963;86:563-86.

18. Kulkarni V, Chandy MJ, Babu KS. Quantitative study of muscle spindles in suboccipital muscles of human foetuses. Neurol India. 2001;49(4):355-9.

19. Boyd-Clark LC, Briggs CA, Galea MP. Muscle spindle distribution, morphology, and density in longus colli and multifidus muscles of the cervical spine. Spine (Phila Pa 1976). 2002;27(7):694-701.

20. Amonoo-Kuofi HS. The density of muscle spindles in the medial, intermediate and lateral columns of human intrinsic postvertebral muscles. J Anat. 1983;136(Pt 3):509-19.

21. Amonoo-Kuofi HS. The number and distribution of muscle spindles in human intrinsic postvertebral muscles. J Anat. 1982;135(Pt 3):585-99.

22. Liu JX, Thornell LE, Pedrosa-Domellöf F. Muscle spindles in the deep muscles of the human neck: a morphological and immunocytochemical study. J Histochem Cytochem. 2003;51(2):175-86.

23. McLain RF, Pickar JG. Mechanoreceptor endings in human thoracic and lumbar facet joints. Spine (Phila Pa 1976). 1998;23(2):168-173.

24. McLain RF. Mechanoreceptor endings in human cervical facet joints. Spine. 1994;19(5):495-501.

25. Yang L, Yang C, Pang X, et al. Mechanoreceptors in diseased cervical intervertebral disc and vertigo. Spine (Phila Pa 1976). 2017;42(8):540-546.

26. Mendel T, Wink CS, Zimny ML. Neural elements in human cervical intervertebral discs. Spine (Phila Pa 1976). 1992;17(2):132-135.

27. Tomlinson J, Zwirner J, Ondruschka B, Prietzel T, Hammer N. Innervation of the hip joint capsular complex: a systematic review of histological and immunohistochemical studies and their clinical implications for contemporary treatment strategies in total hip arthroplasty. PLoS One. 2020;15(2): e0229128. 
28. Moraes MR, Cavalcante ML, Leite JA, et al. The characteristics of the mechanoreceptors of the hip with arthrosis. J Orthop Surg Res. 2011;6:58.

29. Armstrong B, McNair P, Taylor D. Head and neck position sense. Sports Med. 2008;38(2):101-17.

30. Yang L, Chen J, Yang C, et al. Cervical intervertebral disc degeneration contributes to dizziness: a clinical and immunohistochemical study. World Neurosurg. 2018;119:e686-93.

31. Proske U, Gandevia SC. The proprioceptive senses: their roles in signaling body shape, body position and movement, and muscle force. Physiol Rev. 2012;92:1651-97.

32. Tuthill JC, Azim E. Proprioception. Curr Biol. 2018;28(5):R194-203.

33. Riemann BL, Lephart SM. The sensorimotor system, part I: the physiologic basis of functional joint stability. J Athl Train. 2002;37(1):71-9.

34. Peng B. Cervical vertigo: historical reviews and advances. World Neurosurg. 2018;109:347-50.

35. Devaraja K. Approach to cervicogenic dizziness: a comprehensive review of its aetiopathology and management. Eur Arch Otorhinolaryngol. 2018;275(10):2421-33.

36. Brandt T, Bronstein AM. Cervical vertigo. J Neurol Neurosurg Psychiatry. 2001;71(1):8-12.

37. Stensdotter AK, Meisingset I, Pedersen MD, Vasseljen $O$, Stavdahl $\varnothing$. Frequency-dependent deficits in head steadiness in patients with nonspecific neck pain. Physiol Rep. 2019;7(5):e14013.

38. Graven-Nielsen T, Svensson P, Arendt-Nielsen L. Effects of experimental muscle pain on muscle activity and co-ordination during static and dynamic motor function. Electroencephalogr Clin Neurophysiol. 1997;105(2):156-64.

39. Svensson P, Arendt-Nielsen L, Houe L. Muscle pain modulates mastication: an experimental study in humans. J Orofac Pain. 1998;12(1):7-16.

40. Farina D, Arendt-Nielsen L, Merletti R, GravenNielsen T. Effect of experimental muscle pain on motor unit firing rate and conduction velocity. J Neurophysiol. 2004;91(3):1250-9.

41. Sohn MK, Graven-Nielsen T, Arendt-Nielsen L, Svensson P. Inhibition of motor unit firing during experimental muscle pain in humans. Muscle Nerve. 2000;23(8):1219-26.

42. Farina D, Arendt-Nielsen L, Graven-Nielsen T. Experimental muscle pain reduces initial motor unit discharge rates during sustained submaximal contractions. J Appl Physiol (1985). 2005;98(3): 999-1005.

43. Le Pera D, Graven-Nielsen T, Valeriani $M$, et al. Inhibition of motor system excitability at cortical and spinal level by tonic muscle pain. Clin Neurophysiol. 2001;112(9):1633-41.

44. Thunberg J, Ljubisavljevic M, Djupsjöbacka M, Johansson $\mathrm{H}$. Effects on the fusimotor-muscle spindle system induced by intramuscular injections of hypertonic saline. Exp Brain Res. 2002;142(3):319-26.

45. Ciubotariu A, Arendt-Nielsen L, Graven-Nielsen T. The influence of muscle pain and fatigue on the activity of synergistic muscles of the leg. Eur J Appl Physiol. 2004;91(5-6):604-14.

46. Falla D, Farina D, Graven-Nielsen T. Experimental muscle pain results in reorganization of coordination among trapezius muscle subdivisions during repetitive shoulder flexion. Exp Brain Res. 2007;178(3):385-93.

47. Lund JP, Donga R, Widmer CG, Stohler CS. The pain-adaptation model: a discussion of the relationship between chronic musculoskeletal pain and motor activity. Can J Physiol Pharmacol. 1991;69(5):683-94.

48. Falla D, Farina D, Dahl MK, Graven-Nielsen T. Muscle pain induces task-dependent changes in cervical agonist/antagonist activity. J Appl Physiol (1985). 2007;102(2):601-609.

49. Malmström EM, Westergren H, Fransson PA, Karlberg M, Magnusson M. Experimentally induced deep cervical muscle pain distorts head on trunk orientation. Eur J Appl Physiol. 2013;113(10): 2487-99.

50. Falla DL, Jull GA, Hodges PW. Patients with neck pain demonstrate reduced electromyographic activity of the deep cervical flexor muscles during performance of the craniocervical flexion test. Spine (Phila Pa 1976). 2004;29(19):2108-2114.

51. Falla D, Bilenkij G, Jull G. Patients with chronic neck pain demonstrate altered patterns of muscle activation during performance of a functional upper limb task. Spine (Phila Pa 1976). 2004;29(13): 1436-1440.

52. Blouin JS, Siegmund GP, Carpenter MG, Inglis JT. Neural control of superficial and deep neck muscles in humans. J Neurophysiol. 2007;98(2):920-8.

53. De Pauw R, Coppieters I, Kregel J, De Meulemeester K, Danneels L, Cagnie B. Does muscle morphology change in chronic neck pain patients? A systematic review. Man Ther. 2016;22:42-9. 
54. Falla D. Unravelling the complexity of muscle impairment in chronic neck pain. Man Ther. 2004;9(3):125-33.

55. Reddy RS, Tedla JS, Dixit S, Abohashrh M. Cervical proprioception and its relationship with neck pain intensity in subjects with cervical spondylosis. BMC Musculoskelet Disord. 2019;20(1):447.

56. Thunberg J, Hellström F, Sjölander P, Bergenheim $\mathrm{M}$, Wenngren $\mathrm{B}$, Johansson $\mathrm{H}$. Influences on the fusimotor-muscle spindle system from chemosensitive nerve endings in cervical facet joints in the cat: possible implications for whiplash induced disorders. Pain. 2001;91(1-2):15-22.

57. Flor H. Cortical reorganisation and chronic pain: implications for rehabilitation. J Rehabil Med. 2003;(41 Suppl):66-72.

58. Risbud MV, Shapiro IM. Role of cytokines in intervertebral disc degeneration: pain and disc content. Nat Rev Rheumatol. 2014;10(1):44-56.

59. Miller RE, Miller RJ, Malfait AM. Osteoarthritis joint pain: the cytokine connection. Cytokine. 2014;70(2):185-93.

60. Holm S, Indhal A, Solomonow M. Sensorimotor control of the spine. J Electromyogr Kinesiol. 2002;12(3):219-34.

61. Yacovino DA, Hain TC. Clinical characteristics of cervicogenic-related dizziness and vertigo. Semin Neurol. 2013;33(3):244-55.

62. Karnath HO. Subjective body orientation in neglect and the interactive contribution of neck muscle proprioception and vestibular stimulation. Brain. 1994;117(Pt 5):1001-12.

63. Carlsson CA, Pellettieri L. A clinical view of pain physiology. Acta Chir Scand. 1982;148(4):305-13.

64. Appelberg B, Hulliger M, Johansson H, Sojka P. Actions on gamma-motoneurones elicited by electrical stimulation of group III muscle afferent fibres in the hind limb of the cat. J Physiol. 1983;335: 275-92.

65. Capra NF, Hisley CK, Masri RM. The influence of pain on masseter spindle afferent discharge. Arch Oral Biol. 2007;52(4):387-90.

66. Johansson H, Sojka P. Pathophysiological mechanisms involved in genesis and spread of muscular tension in occupational muscle pain and in chronic musculoskeletal pain syndromes: a hypothesis. Med Hypotheses. 1991;35(3):196-203.

67. Revel M, Andre-Deshays C, Minguet M. Cervicocephalic kinesthetic sensibility in patients with cervical pain. Arch Phys Med Rehabil. 1991;72(5): 288-91.

68. Chen X, Treleaven J. The effect of neck torsion on joint position error in subjects with chronic neck pain. Man Ther. 2013;18(6):562-7.

69. Treleaven J, Takasaki H. High variability of the subjective visual vertical test of vertical perception, in some people with neck pain-should this be a standard measure of cervical proprioception? Man Ther. 2015;20(1):183-8.

70. Geisinger D, Ferreira E, Suarez A, Suarez H. Head tilt response: a complementary test to the subjective visual vertical. J Vestib Res. 2010;20(5):381-9.

71. Kristjansson E, Oddsdottir GL. "The Fly": a new clinical assessment and treatment method for deficits of movement control in the cervical spine. Spine (Phila Pa 1976).2010;35(23):E1298-E1305

72. Tjell C, Rosenhall U. Smooth pursuit neck torsion test: a specific test for cervical dizziness. Am J Otol. 1998;19(1):76-81.

73. Treleaven J, Jull G, LowChoy N. Smooth pursuit neck torsion test in whiplash-associated disorders: relationship to self-reports of neck pain and disability, dizziness and anxiety. J Rehabil Med. 2005;37(4):219-23.

74. Woodhouse A, Liljebäck P, Vasseljen O. Reduced head steadiness in whiplash compared with nontraumatic neck pain. J Rehabil Med. 2010;42(1): $35-41$.

75. Bagust J. Assessment of verticality perception by a rod-and-frame test: preliminary observations on the use of a computer monitor and video eye glasses. Arch Phys Med Rehabil. 2005;86(5):1062-4.

76. Grod JP, Diakow PR. Effect of neck pain on verticality perception: a cohort study. Arch Phys Med Rehabil. 2002;83(3):412-5.

77. de Zoete RMJ, Osmotherly PG, Rivett DA, Farrell SF, Snodgrass SJ. Sensorimotor control in individuals with idiopathic neck pain and healthy individuals: a systematic review and meta-analysis. Arch Phys Med Rehabil. 2017;98(6):1257-71.

78. de Zoete RMJ, Osmotherly PG, Rivett DA, Snodgrass SJ. Seven cervical sensorimotor control tests measure different skills in individuals with chronic idiopathic neck pain. Braz J Phys Ther. 2020;24(1): 69-78.

79. de Vries J, Ischebeck BK, Voogt LP, et al. Joint position sense error in people with neck pain: a systematic review. Man Ther. 2015;20(6):736-44. 
80. Alahmari KA, Reddy RS, Silvian PS, Ahmad I, Kakaraparthi VN, Alam MM. Association of age on cervical joint position error. J Adv Res. 2017;8(3): 201-7.

81. Alahmari KA, Reddy RS, Silvian P, Ahmad I, Nagaraj $\mathrm{V}$, Mahtab M. Influence of chronic neck pain on cervical joint position error (JPE): Comparison between young and elderly subjects. J Back Musculoskelet Rehabil. 2017;30(6):1265-71.

82. Cheng $\mathrm{CH}$, Wang JL, Lin JJ, Wang SF, Lin KH. Position accuracy and electromyographic responses during head reposition in young adults with chronic neck pain. J Electromyogr Kinesiol. 2010;20(5):1014-20.

83. Edmondston SJ, Chan HY, Ngai GC, et al. Postural neck pain: an investigation of habitual sitting posture, perception of "good" posture and cervicothoracic kinaesthesia. Man Ther. 2007;12(4):363-71.

84. Elsig S, Luomajoki H, Sattelmayer M, Taeymans J, Tal-Akabi A, Hilfiker R. Sensorimotor tests, such as movement control and laterality judgment accuracy, in persons with recurrent neck pain and controls. A case-control study. Man Ther. 2014;19(6): 555-61.

85. Grip H, Sundelin G, Gerdle B, Karlsson JS. Variations in the axis of motion during head repositioning-a comparison of subjects with whiplashassociated disorders or non-specific neck pain and healthy controls. Clin Biomech (Bristol, Avon). 2007;22(8):865-73.

86. Rix GD, Bagust J. Cervicocephalic kinesthetic sensibility in patients with chronic, nontraumatic cervical spine pain. Arch Phys Med Rehabil. 2001;82(7):911-9.

87. Kristjansson E, Dall'Alba P, Jull G. A study of five cervicocephalic relocation tests in three different subject groups. Clin Rehabil. 2003;17(7):768-74.

88. Lee HY, Teng CC, Chai HM, Wang SF. Test-retest reliability of cervicocephalic kinesthetic sensibility in three cardinal planes. Man Ther. 2006;11(1): 61-8.

89. Lee HY, Wang JD, Yao G, Wang SF. Association between cervicocephalic kinesthetic sensibility and frequency of subclinical neck pain. Man Ther. 2008;13(5):419-25.

90. Palmgren PJ, Andreasson D, Eriksson M, Hägglund A. Cervicocephalic kinesthetic sensibility and postural balance in patients with nontraumatic chronic neck pain-a pilot study. Chiropr Osteopat. 2009;17:6.

91. Teng CC, Chai H, Lai DM, Wang SF. Cervicocephalic kinesthetic sensibility in young and middle-aged adults with or without a history of mild neck pain. Man Ther. 2007;12(1):22-8.

92. Woodhouse A, Vasseljen O. Altered motor control patterns in whiplash and chronic neck pain. BMC Musculoskelet Disord. 2008;9:90.

93. Armstrong BS, McNair PJ, Williams M. Head and neck position sense in whiplash patients and healthy individuals and the effect of the cranio-cervical flexion action. Clin Biomech (Bristol, Avon). 2005;20(7):675-84.

94. Knapstad MK, Goplen FK, Ask T, Skouen JS, Nordahl SHG. Associations between pressure pain threshold in the neck and postural control in patients with dizziness or neck pain-a cross-sectional study. BMC Musculoskelet Disord. 2019;20(1):528.

95. Uthaikhup S, Jull G, Sungkarat S, Treleaven J. The influence of neck pain on sensorimotor function in the elderly. Arch Gerontol Geriatr. 2012;55(3): 667-72.

96. Röijezon U, Björklund M, Bergenheim M, Djupsjöbacka M. A novel method for neck coordination exercise-a pilot study on persons with chronic nonspecific neck pain. J Neuroeng Rehabil. 2008;5:36.

97. Beinert $\mathrm{K}$, Taube $\mathrm{W}$. The effect of balance training on cervical sensorimotor function and neck pain. J Mot Behav. 2013;45(3):271-8.

98. Duray M, Şimşek Ş, Altuğ F, Cavlak U. Effect of proprioceptive training on balance in patients with chronic neck pain. Agri. 2018;30(3):130-7.

99. Saadat M, Salehi R, Negahban H, Shaterzadeh MJ, Mehravar M, Hessam M. Traditional physical therapy exercises combined with sensorimotor training: the effects on clinical outcomes for chronic neck pain in a double-blind, randomized controlled trial. J Bodyw Mov Ther. 2019;23(4):901-7.

100. Falla D, Jull G, Russell T, Vicenzino B, Hodges P. Effect of neck exercise on sitting posture in patients with chronic neck pain. Phys Ther. 2007;87(4): 408-17.

101. Blomgren J, Strandell E, Jull G, Vikman I, Röijezon U. Effects of deep cervical flexor training on impaired physiological functions associated with chronic neck pain: a systematic review. BMC Musculoskelet Disord. 2018;19(1):415.

102. Jull G, Falla D. Does increased superficial neck flexor activity in the craniocervical flexion test reflect reduced deep flexor activity in people with neck pain? Man Ther. 2016;25:43-7.

103. Jull GA, Falla D, Vicenzino B, Hodges PW. The effect of therapeutic exercise on activation of the deep 
cervical flexor muscles in people with chronic neck pain. Man Ther. 2009;14(6):696-701.

104. Jull GA, O'Leary SP, Falla DL. Clinical assessment of the deep cervical flexor muscles: the craniocervical flexion test. J Manipul Physiol Ther. 2008;31(7): 525-33.

105. Jull G, Trott P, Potter H, et al. A randomized controlled trial of exercise and manipulative therapy for cervicogenic headache. Spine (Phila Pa 1976). 2002;27(17):1835-1843.

106. Falla D, O'Leary S, Farina D, Jull G. The change in deep cervical flexor activity after training is associated with the degree of pain reduction in patients with chronic neck pain. Clin J Pain. 2012;28(7): 628-34.

107. Schomacher J, Falla D. Function and structure of the deep cervical extensor muscles in patients with neck pain. Man Ther. 2013;18(5):360-6.

108. O'Leary S, Falla D, Elliott JM, Jull G. Muscle dysfunction in cervical spine pain: implications for assessment and management. J Orthop Sports Phys Ther. 2009;39(5):324-33.

109. Johnston V, Jull G, Souvlis T, Jimmieson NL. Neck movement and muscle activity characteristics in female office workers with neck pain. Spine (Phila Pa 1976). 2008;33(5):555-563.

110. Fernández-de-las-Peñas C, Albert-Sanchís JC, Buil M, Benitez JC, Alburquerque-Sendín F. Cross-sectional area of cervical multifidus muscle in females with chronic bilateral neck pain compared to controls. J Orthop Sports Phys Ther. 2008;38(4):175-80.

111. Uhlig Y, Weber BR, Grob D, Müntener M. Fiber composition and fiber transformations in neck muscles of patients with dysfunction of the cervical spine. J Orthop Res. 1995;13(2):240-9.

112. Cagnie B, Cools A, De Loose V, Cambier D, Danneels L. Differences in isometric neck muscle strength between healthy controls and women with chronic neck pain: the use of a reliable measurement. Arch Phys Med Rehabil. 2007;88(11):1441-5.

113. Jordan A, Mehlsen J, Ostergaard K. A comparison of physical characteristics between patients seeking treatment for neck pain and age-matched healthy people. J Manipul Physiol Ther. 1997;20(7):468-75.

114. Lee H, Nicholson LL, Adams RD. Neck muscle endurance, self-report, and range of motion data from subjects with treated and untreated neck pain. J Manipul Physiol Ther. 2005;28(1):25-32.

115. Peolsson A, Kjellman G. Neck muscle endurance in nonspecific patients with neck pain and in patients after anterior cervical decompression and fusion. J Manipul Physiol Ther. 2007;30(5):343-50.

116. Schomacher J, Farina D, Lindstroem R, Falla D. Chronic trauma-induced neck pain impairs the neural control of the deep semispinalis cervicis muscle. Clin Neurophysiol. 2012;123(7):1403-8.

117. Lindstrøm R, Schomacher J, Farina D, Rechter L, Falla D. Association between neck muscle coactivation, pain, and strength in women with neck pain. Man Ther. 2011;16(1):80-6.

118. Elliott JM, O'Leary SP, Cagnie B, Durbridge G, Danneels L, Jull G. Craniocervical orientation affects muscle activation when exercising the cervical extensors in healthy subjects. Arch Phys Med Rehabil. 2010;91(9):1418-22.

119. O'Leary S, Cagnie B, Reeve A, Jull G, Elliott JM. Is there altered activity of the extensor muscles in chronic mechanical neck pain? A functional magnetic resonance imaging study. Arch Phys Med Rehabil. 2011;92(6):929-34.

120. Conley MS, Stone MH, Nimmons M, Dudley GA. Resistance training and human cervical muscle recruitment plasticity. J Appl Physiol (1985). 1997;83(6):2105-2111.

121. Conley MS, Stone MH, Nimmons M, Dudley GA. Specificity of resistance training responses in neck muscle size and strength. Eur J Appl Physiol Occup Physiol. 1997;75(5):443-8.

122. Schomacher J, Erlenwein J, Dieterich A, Petzke F, Falla D. Can neck exercises enhance the activation of the semispinalis cervicis relative to the splenius capitis at specific spinal levels? Man Ther. 2015;20(5):694-702.

123. Schomacher J, Petzke F, Falla D. Localised resistance selectively activates the semispinalis cervicis muscle in patients with neck pain. Man Ther. 2012;17(6): 544-8.

124. Onyewu O, Manchikanti L, Falco FJ, et al. An update of the appraisal of the accuracy and utility of cervical discography in chronic neck pain. Pain Physician. 2012;15(6):E777-806.

125. Falco FJ, Datta S, Manchikanti L, et al. An updated review of the diagnostic utility of cervical facet joint injections. Pain Physician. 2012;15(6):E807-38.

126. Sremakaew M, Jull G, Treleaven J, Barbero M, Falla D, Uthaikhup S. Effects of local treatment with and without sensorimotor and balance exercise in individuals with neck pain: protocol for a randomized controlled trial. BMC Musculoskelet Disord. 2018;19(1):48. 